\title{
The New Regionalism in the Developing World: Case Studies of the ASEAN Free Trade Area and the UEMOA Common Market
}

\author{
MARC HOUNGBEDJI
}

This article examines the dynamics at regional level that have been influencing and shaping the course of regional integration processes in Southeast Asia and West Africa since the early 1990s. The winding down of the Cold War led to a revival of interest in regional arrangements elsewhere, especially in many parts of the developing world, where regional economic blocs have been emerging while efforts to strengthen the existing ones have been going on. Using the particular case studies of the ASEAN Free Trade Area (AFTA) and the UEMOA Common Market (CM), this paper argues that beyond the direct impact of the proliferation of regional blocs elsewhere and the dynamic effects of globalization, which induce tight competition for production locations, trade shares, stock market capital and foreign direct investment (FDI), the adoption, acceleration and consolidation of the AFTA and UEMOA CM schemes, mostly respond to the necessity to balance the FDI diverting effects and the growing ascent of China and Nigeria emerging as regional powers. The logic of balance-of-power and the imperious necessity to get regional and international visibility in the globalizing world induced ASEAN and UEMOA leaders to undertake important regional integrative initiatives and policies conducive to create a single and competitive regional bloc, respectively within Southeast Asia and West Africa.

Keywords: New regionalism, Global Capitalism, Developing World, AFTA, UEMOA CM, Emerging Regional Powers, Regional Leadership Competition

ASEAN: Association of Southeast Asian Nations

UEMOA: West African Economic and Monetary Union

\footnotetext{
'Doctoral Student (Asia Pacific Studies), Ritsumeikan, Asia Pacific University, Beppu City, Japan; Staff (2003-2005), Department of African \& Middle East Affairs, Ministry of Foreign Affairs \& African Integration, Benin; Email: marcho07@apu.ac.jp; I am particularly grateful to two anonymous scholars for their invaluable comments on the earlier version of this paper. I associate Professor Hidetaka Yoshimatsu with these scholars.
} 


\section{INTRODUCTION}

The end of the 1980s led to global changes in world politics and economics. 1 One of the outstanding events highlighting these changes is connected to the proliferation of regional integration blocs. This phenomenon, perceptible in the 1950s and 1960s through the establishment of the European Economic Community (EEC) and regional groupings initiated by developing countries, notably the newly independent ones, has intensified dramatically with the end of the Cold War, with the multiplication of regional integration blocs all over the world. The resurgence of interest in regionalism, at this stage, has had a particular echo in the developing world where there has been a rise of movements to harmonize or unify economic policies, to promote liberalization or other forms of cooperative regional arrangements. ${ }^{1}$ As Bach (2005: 178) put it, "acronyms were updated, founding charters refurbished, mandates turned to new ambitions, etc."

Thus, in East Asia, the Association of Southeast Asian Nations (ASEAN), well known as a regional grouping struggling since its inception (1967) to embrace effective regional economic cooperation, has switched to improving regional trade flows at a higher level by concluding the ASEAN Free Trade Area (AFTA) agreement in January 1992. In the same optic, the Declaration and Treaty establishing the new Southern African Development Community (SADC) was signed with the principal objectives to "give the organization a legal and more formal status" and above all "to shift the focus of the organization from co-ordination of development projects to the more complex task of integrating the economies of member States."2 Likewise, in West Africa, the leaders of ex-French colonies gathered in Dakar (Senegal) in January 1994, and created the West African Economic and Monetary Union (UEMOA) with a series of programmes from which they decided to set up a Common Market.

Subsequently, efforts to speed up and consolidate regional integrative arrangements were perceptible among the participating countries. Bach (2005) correctly noted that "more recently, pressures for greater transparency has prompted the development of website, with the result being a new capacity to circulate information on decisions, programmes and ambitions." Particularly in West Africa and Southeast Asia, member governments were committed to sustaining their respective liberalization projects, from speeding up their pace to widening their scope. Indeed, throughout the 1990 s till the early 2000 s, commitments to advance tariff liberalization were forthcoming, while programmes were developed to address non-tariff barriers and facilitate free trade within both regions through a range of supplementary programmes.

The resurgence of regionalism in Southeast Asia and West Africa over the last decade has aroused the interest of scholars. Most of them dealing with the new wave of regionalism in these parts of developing world centered their 
approaches and analyses on global systemic factors, especially on changes occurring in the international economic environment. Yet, approaching from global systemic dyads the main dynamics driving the new wave of regionalism since the 1990s is very limited and approximate, especially in the developing world where both the end of the Cold War and the triumph of global capitalism led to profound re-composition of geopolitical and geo-economic landscapes. In that optic, this article seeks to provide an analytical framework for a comprehensive assessment of the main dynamics driving regional integration processes in Southeast Asia and West Africa in this globalization and post-Cold War era, by highlighting the importance of regional dyadic competition.

To this end, the following questions need to be addressed: First, what kind of initiatives, policies and programmes have the ASEAN and UEMOA leaders adopted under the AFTA agreement and UEMOA CM proposals in embarking on the liberalization process? Second, how has regional economic and leadership competition from neighboring emerging powers-China and Nigeria-influenced and shaped the course of these programmes and policies?

To answer the questions above, this paper is organized as follows: in order to draw an analytical framework for this article, section II surveys the scholarly literature on determining factors that explain the adoption, acceleration and consolidation of regional integration processes within the ASEAN and UEMOA blocs. Section III and IV examine the initiatives, policies and programmes adopted respectively by the ASEAN and UEMOA leaders in embarking on liberalization under AFTA and UEMOA CM, as well as the regional dyads influencing the course of these respective schemes. Section V covers an analysis of the two case studies. The conclusion summarizes the main arguments defended in this paper, as well as their implications for regional integration processes in other parts of the developing world.

\section{THE LITERATURE ON REGIONALISM IN SOUTHEAST ASIA AND WEST AFRICA SINCE THE EARLY 1990S: STRENGTHS AND LIMITS}

The growing importance of regionalism, since the end of the Cold War, has carried a voluminous body of literature in its trail. The adoption of the North American Free Trade Agreement (NAFTA), the consolidating process of economic integration in Europe, the adoption of the ASEAN free trade agreement, the creation of the SADC, UEMOA and Mercosur, etc. spawned an array of scholarly publications seeking to explain the causes and implications underlying the formation and consolidation of various regional arrangements. Many scholars involved in these debates centered on international politics and international economics approaches to explain the new wave of regionalism, particularly in Southeast Asia and West Africa. 


\section{International politics approaches}

Emphasizing their interpretation on power, security and survival as central variables, scholars defending international politics approaches analyzed the formation of regional groupings from the early 1990s as strategic responses to political power competition, marking no difference between political/strategic regionalism and economic regionalism (Hurrell, 1995: 49). In this vein, Buszynski (1997: 557) explained the ASEAN free trade agreement as an economic instrument that ASEAN members adopted to give the Association a new political purpose after the end of US-Soviet confrontation and the resolution of the Cambodian crisis, and to provide the foundation for Southeast Asian regionalism in the 1990s. Ravenhill (1995: 850-856) developed a similar argument, observing that the demise of the Soviet Union removed a potential external threat and offered to the Association the opportunity to seek a new raison d'être at a period when growing regional arrangements elsewhere posed another potential threat to its development. In this international politics interpretation of events, diminishing superpower confrontation between the United Stated and the Soviet Union from the late 1980 s reduced not only the strategic significance of the ASEAN to external powers, particularly to the US, but also weakened the utility of the Association to its own members.

With respect to West Africa, Paoloni (1996: 38-40) observed that the adoption of the Maastricht Treaty in 1992 launched the transition from the French franc - as with many other West European national currencies-to the 'euro'. Hence, the perspective for European Union countries to move to a single currency in 1999 raised a puzzling question of whether, "when the euro takes over from French franc, there will be a mechanism for fixing the parities of the CFA franc in the relation with euro." Indeed, since the common currency used by West African Francophone States (CFA franc) is pegged to the French franc and its convertibility was guaranteed by the French Treasury, concerns have been raised about the ability of the latter to maintain an unlimited convertibility guarantee in the long term. More importantly, how to be able to take advantage of potential gains the French Treasury will reap from the single currency [euro], in terms of lower interest rates and access to the euro market, became a veritable concern for the countries that use the CFA franc (Ibid: 40).

These diverse reasons accounting for the decision by respective regional governments to adopt the AFTA agreement and to create the UEMOA are certainly plausible, given the critical international politico-economic environment in the early 1990s. However, these factors are less capable of explaining why original scopes of the AFTA and UEMOA CM were sustained and expanded further to other strategic sectors. The international politics interpretation of the ASEAN and UEMOA leaders' commitment to set up and consolidate a regional bloc 
within Southeast Asia and West Africa is virtually limited by its realist tendency to consider the actions of state actors as driven purely by global systemic forces. More importantly, the international politics approaches failed to capture that the end of the historic confrontation between the United Stated and the Soviet Union in the late 1980 s has led to the emergence of new regional hegemonic powers like China and Nigeria, whose growing influence, aspiration for regional leadership and deeper economic reforms, triggered the surrounding weaker States' commitment to set up a counter-balancing regional bloc. Walt's balance-of-power theory ${ }^{3}$ explains this realistic perspective well.

Besides the international politics approaches, other scholars analyzed the adoption of the AFTA agreement and the creation of the UEMOA from international economics approaches.

\section{International Economics Approaches}

Two tendencies deriving from theoretical traditions in international economics dominated these approaches: trade-centred explanations and FDI-centred explanations.

The trade-centred explanations of the proliferation of regional blocs are defended in Denoon \& Colbert's political economy approach. In considering the low rate of intra-ASEAN trade in the late 1980s (17.4\%), they observed that the end of the Cold War offered the grouping an opportunity to undertake the enlargement of its membership, and to seek deeper economic integration. From their perspective, the desire to take better advantage of a regional market of 300 million people [now 567 million] ${ }^{4}$ was an important motive behind the ASEAN leaders' efforts to speed up and establish the AFTA (1998: 505-523). This stimulus, according to them, was reinforced by what the ASEAN leaders saw as a movement towards regional trading blocs, represented by the EU and NAFTA.

With regard to West Africa, Gambari (1991: 39-40) observed that the percentage of West African total external trade is the smallest of all other world regions, and specified that the most common figures used to evaluate this record indicated a proportion between $2.2 \%$ to $3.3 \%$. The main reasons explaining the poor record of intra-regional trade, according to Paoloni (1996), Vallejo (2001: 535) and Dennis \& Brown (2003: 229-249), were ascribed to the diversity of currencies and economic systems, taken together with the fact that national economies in the subregion are competitive rather than complementary. Under these circumstances, the franc-zone countries in West African subregion could take advantage over these diversities and promote efficient market liberalization among themselves by creating and consolidating a regional economic and monetary bloc, as they use a common language, a common currency, and have administrative and financial structures modeled along similar lines. 
This trade-centred explanation constitutes a useful corrective to international politics interpretations that emphasize only systemic factors. However, this approach, focused on exchange or trade relations as the incentive factors triggering the adoption of the AFTA agreement and the creation of UEMOA, is limited in neglecting the investment dimension. Thereupon, other scholars interpreted the proliferation and consolidation of regional economic arrangements from the early 1990s, particularly in the developing world, as a strategic option to increase their ability to attract FDI. In this logic, Bowles (2000: 438) observed that the regional grouping of developing countries offered the possibility of attracting such capital inflows since a group of countries together offer a more attractive package than a single country.

As such, the single regional market project was regarded by the ASEAN countries as a means to attract FDI that, at the beginning of the 1990s, appeared in danger of being diverted to other newly emerging markets (Bowles \& MacLean, 1996: 336; Chia, 1998: 218; Low, 1996: 198; Ravenhill, 1995: 854). Likewise, by using the same currency, risks and transaction costs are reduced within the UEMOA zone, and this could help stimulate investment and growth (Medhora, 1996: 251). Medhora's argument is consistent with the one defended by Bach (1983: 605-623) to explain the creation of the West African Economic Community (CEAO) in 1973. From Bach's perspective, the main reason why the francophone countries had supported the creation of the CEAO was in their belief that it would promote the growth of a wider market, which would attract foreign investors. Thus, in these scholars' viewpoint, understanding the development of the AFTA and the UEMOA CM processes resides in the political economy of FDI. Although their approach is apt, it only emphasizes the influence of global FDI trends, thereby neglecting the growing ASEAN and UEMOA leaders' concerns over the increasing volume of FDI flowing into neighboring giants (China and Nigeria) at the expense of their national economies.

In sum, neither the international politics approaches centred on systemic pressures nor the international economic theories centred on trade and FDI, are sufficient to explain the initiation of the AFTA and UEMOA CM schemes, as well as the main dynamics driving the acceleration, expansion and consolidation of their processes. By emphasizing their perspectives only on global systemic factors, most scholars dealing with new regionalism in Southeast Asia and West Africa in the post-Cold War era failed to capture that growing economic competition from neighboring emerging powers-China and Nigeria-for production locations, trade shares, stock market capital and FDI, is likely to keep them from gaining international visibility. The increasing gap in economic patterns of comparative advantages, logically, will trigger, on their part, strategic balancing responses. The following sections highlight the importance of regional dyadic competition. 


\section{THE ASEAN FREE TRADE AREA (AFTA)}

\section{The AFTA Proposals}

The ASEAN is a regional grouping composed of ten member countries. ${ }^{5}$ At the $4^{\text {th }}$ ASEAN Summit held in Singapore in January 1992, the member governments adopted the Agreement on AFTA; a free trade area understood as a form of regional economic integration, where the participating nations remove all trade impediments amongst themselves, but retain their freedom to determine their own policies vis-à-vis the outside world. Introduced in January 1993, the AFTA Agreement was envisioned to liberalize trade within ASEAN through progressive tariff reductions on selective products, to facilitate the integration of ASEAN as a market and a competitive production base, and to attract increased levels of foreign investment. The initial AFTA programme provided for a reduction on intra-ASEAN trade barriers of tariffs (ranging from 0 to $5 \%$ ) and removal of non-tariff barriers. From 1 January 1993 to the revised target date of 20036, the whole programme was designed to be achieved via the Common Effective Preferential Tariff (CEPT) scheme.

\section{The Process of the AFTA Implementation}

Two important aspects characterized the process of the AFTA implementation: (i) the acceleration of the AFTA project, and (ii) the expansion and consolidation of its initial scope.

\section{(1) The Acceleration of the AFTA Project}

The inception of the AFTA project on 1 January 1994 was immediately supported by the member governments who agreed to implement the CEPT programme of tariffs reduction as of that date. This good sign for the AFTA implementation by the ASEAN countries was evident not only in the increasing number of items included in the CEPT product lists, but more importantly, in consistent efforts to speed up the AFTA process through tariff disarmament. Indeed, as of 1 January 1994 , of the total of just over 15,000 tariff lines identified by the member states, more than $88 \%$ were included in the CEPT (ASEAN Secretariat, 1994).

Encouraged by this commitment, the ASEAN governments adopted five improvements to the $\mathrm{AFTA}^{7}$ at the Bangkok Summit on 15 December 1995. In particular, the 0-5\% CEPT target for manufactured goods was re-scheduled, to be reached by January 2003 instead of 2008; member governments agreed to develop a regional mechanism to protect intellectual property ${ }^{8}$ as well as 
a mechanism for dispute settlement in the AFTA.9 In December 1997, at the $2^{\text {nd }}$ ASEAN Informal Summit held in Kuala Lumpur, a further set of advances to the AFTA commitments occurred after the Asian financial crisis began in July 1997 (Nesadurai, 2003: 62-63). In October 1998, the $12^{\text {th }}$ AFTA Council agreed to accelerate the implementation of the AFTA by calling on member governments to reduce as many tariff lines as possible to $0 \%$ by 2003. A good sign for the AFTA implementation was also perceptible in tariff disarmament.

The tariff disarmament unfolded through two channels: the CEPT tariff liberalization and the reduction of non tariff barriers (NTBs). The achievements of the AFTA regarding the CEPT tariff liberalization were substantial. By 2004, more than $99 \%$ of the products in the CEPT Inclusion List (IL) of the ASEAN-6 were brought down to the 0-5\% tariff range (ASEAN Annual Report, 20032004: 17). In 2005, $64.12 \%$ of products in the IL of these countries had zero tariffs (ASEAN Annual Report, 2004-2005: 25). Overall, by 2005, 92\% of all products in the IL of the ten member countries (ASEAN-10) had tariffs between $0-5 \%$. As of 1 January 2005, $86.91 \%$ of their products traded in the region have been moved into the CEPT Inclusion List, up from $80 \%$ in 2003/2004. Similar efforts were perceptible regarding the reduction of non-tariff barriers, where the ASEAN governments completely eliminated customs surcharges by the end of 1996, while technical NTBs were to be addressed through programmes promoting transparency and harmonization as well as through mutual recognition arrangements (Nesadurai, 2003: 70). This rapid tariff disarmament encouraged the member governments to expand and consolidate the AFTA's initial project.

\section{(2) Expansion and Consolidation of the AFTA Project}

At the $5^{\text {th }}$ ASEAN Summit held in Bangkok in December 1995, the member governments decided to expand AFTA's initial scope by adopting a range of complementary programmes. To consolidate the whole process, they adopted the ASEAN Vision 2020 in October 2003 at their $9^{\text {th }}$ Summit, aimed at establishing the ASEAN Economic Community.

Regarding the expansion of the AFTA initial project, three potential and strategic sectors were identified by the member countries to back the liberalization under the AFTA's initial scope, namely industry, investment and services. Basic agreements were subsequently signed to promote regional cooperation in each sector. The Basic Agreement on ASEAN Industrial Cooperation Scheme 10 (AICO) was signed by the ASEAN Economic Ministers (AEM) and was launched in April 1996. Actually, the AICO was instituted as a way of speeding up trade liberalization for specific products between particular firms engaged in transnational production 
in the ASEAN (Nesadurai, 2003: 61). Similarly, in order to further enhance the region's capacity of attracting higher and more sustainable levels of FDI flows, the Framework Agreement on the ASEAN Investment Area (AIA) was signed in October 1998 by the AEM 11 , which was reinforced two months later by the 'Statement on Bold Measures'12 issued at the $6^{\text {th }}$ ASEAN Summit. Regional cooperation in services inspired the ASEAN Framework Agreement on Services (AFAS), signed in December 1995, aimed at liberalizing trade in services within the ASEAN, while its goal was to eventually establish an ASEAN free trade area in services by 2020 (ASEAN Secretariat, 1995: 31). The AFAS committed member governments to further negotiations to liberalize seven key service industries, namely finance and bank, tourism, telecommunications, shipping, air transport, construction and business services. ${ }^{13}$

The expansion of the AFTA's initial scope was consolidated by important agreements adopted at the Bali Summit. Indeed, the Bali Concord II, signed at the $9^{\text {th }}$ ASEAN Summit in October 2003, inaugurated the ASEAN Vision 2020, where the ASEAN leaders agreed to establish the ASEAN Economic Community (AEC) based on the elimination of remaining tariff and non-tariff barriers (NTBs) between member states by the revised target year of 2015. Envisioned as the next stage and end-goal of regional economic integration beyond the AFTA, the AEC project aims at establishing ASEAN as single regional market and production base in Southeast Asia, turning the diversity that characterizes the region into opportunities for business complementation to make the ASEAN region a more dynamic and stronger segment of the global supply chain.

To this end, a number of strategies have been adopted. First, the member governments were committed to strengthening the institutional mechanisms of the ASEAN, notably improving the existing Dispute Settlement Mechanism (DSM) designed to ensure expeditious and legally binding resolution of any economic dispute. More recently at their $13^{\text {th }}$ Summit held in Singapore in November 2007, they signed the ASEAN Charter, envisioned to "transform the ASEAN from being a loosely organized political grouping to a more rules-based international organization with a legal personality under international law, and from having a state-centric focus to a more people-centred orientation," 14 thereby paving the way for a closer integration within the group.

The second step towards the realization of the AEC foresees to remove by 2010, to the extent feasible and agreeable to all member countries, tariff and non-tariff barriers to free flow of business persons, goods, services, skilled labor and talents, and a freer flow of capital, along with equitable economic development and reduced poverty and socio-economic disparities within and across its member states. More specifically, the member countries agreed to advance the elimination of tariffs on $85 \%$ of the products in the priority sectors by three years to 
2007 for the ASEAN-6 and to 2012 for the CLMV, instead of 2010 and 2015 under the AFTA scheme (Secretariat 2005: 24-25). In this perspective, at their $39^{\text {th }}$ Meeting held on 24 August 2007 in Makati City (Philippines), the AEM endorsed the AEC Blueprint conducive to speed up the regional integration process and achieve the targeted goals of establishing the AEC by 2015 , instead of 2020 as originally planned.15

In sum, the AFTA process has been marked by the extension and consolidation of its initial scope to include strategic cooperation projects and policies, backed by an eager will of the ASEAN leaders to speed up the establishment of the single regional bloc, and endow the community with a veritable institutional mechanism. But fundamentally, how has regional economic and leadership competition from China as a neighboring emerging power been influencing and shaping the programs and policies adopted and implemented by the ASEAN governments since the early 1990s?

\section{The AFTA Process in the Context of Regional Economic and Leadership Competition from China}

A number of factors stemming from the global systemic level have influenced the initiation of the AFTA agreement as well as its implementation process, as explained in the literature review. However, other important ones deriving from regional level merit particular attention, notably the net increase of FDI flows into China, the 1997 Asian financial crisis, and China's accession into the World Trade Organization (WTO). The cumulative effects of these factors have set up China as a regional economic power, and has dramatically changed in the region, patterns of comparative advantage and competitiveness at the expense of Southeast Asian economies; a critical situation that induced ASEAN leaders to revise and expand the initial project of the AFTA, and accelerate its realization.

\section{(1) The Net Increase of FDI Flows into China}

Over the last decade, and in anticipation of its accession to the WTO, the Chinese authorities have accelerated and deepened strategic economic reforms, which led to (i) FDI diversion from Southeast Asia to China by Chinese business communities, (ii) growth in export-oriented FDI from Hong Kong, Macau and Taiwan, and (iii) local-market oriented FDI from the U.S., Western Europe and Japan. As a result, the end of the 1990s witnessed the emergence of China as one of the most important destinations for FDI, as shown in Table 1 and Table 2 . 
Table 1. FDI flows in Selected Asian EConomies, 1988-1993

(in US\$ million)

\begin{tabular}{l|c|c|c|c|c|c|c}
\hline Selected East Asian Economies & 1988 & 1989 & 1990 & 1991 & 1992 & 1993 & $1988-93$ \\
\hline Newly Industrializing economies & 5,485 & 5,249 & 7,620 & 7,275 & 8,159 & 8,262 & 42,050 \\
\hline South Korea & 871 & 758 & 715 & 1,116 & 550 & 516 & 4,526 \\
\hline Singapore & 3,655 & 2,887 & 5,575 & 4,888 & 6,730 & 6,829 & 30,564 \\
\hline Taiwan & 959 & 1,604 & 1,330 & 1,271 & 879 & 917 & 6,960 \\
\hline China & 3,194 & 3,393 & 3,487 & 4,366 & 11,156 & 26,000 & 51,596 \\
\hline Southeast Asia & 3,336 & 4,688 & 6,399 & 8,038 & 8,590 & 8,739 & 39,790 \\
\hline Indonesia & 576 & 682 & 1,093 & 1,482 & 1,777 & 2,004 & 7,614 \\
\hline Malaysia & 719 & 1,668 & 2,332 & 3,998 & 4,469 & 4,351 & 17,537 \\
\hline Philippines & 936 & 563 & 530 & 544 & 228 & 763 & 3,564 \\
\hline Thailand & 1,105 & 1,775 & 2,444 & 2,014 & 2,116 & 1,621 & 11,075 \\
\hline
\end{tabular}

SOURCE: Asian Development Bank, 1995: 17, Table 1.3 (in J. L. H. Tan, 1996: 3).

A closer observation of the data in Table 1 suggests that, during the period 1988-1991, average annual flows into Southeast Asia were greater than the flows into China. However, the reverse happened in 1992 and since then, the gap between the two flows has expanded with nearly double flows records annually into China, increasing from US\$26 billion in 1993 (Table 1) to US\$ 40 billion in 1999 (Table 2). More explicitly, the data in Table 2 reveal that although China was already substantially receiving larger shares than the ASEAN economies during the period 1992-97, the trends diverged spectacularly after 1999, so that FDI flows into ASEAN fell substantially by 2002, to half the level of 1999.16 In 2002 , the net unbalance in FDI shares, with US\$ $\$ 2,700$ billion for China and US $\$ 13,957$ billion for the ASEAN respectively, made the Singaporean Prime Minister Goh Chok Tong publicly voice ASEAN concerns about regional economic competition from an emerging China since the early 1990s:

ASEAN has to deal with the challenges and opportunities posed by a rising China. China has drawn in proportionately more investments than ASEAN after 1997. Rightfully, we should not be seeing such a trend. ASEAN has a combined population which is half that of China's. It is not a negligible market. ASEAN opened its economies to foreign investors, years before China did. Its economic institutions were more developed than China's. But push factors have reduced FDI inflows into ASEAN, as much as China's pull factor has. ${ }^{17}$

This statement actually underscores the perception of economic threat the ASEAN countries have been facing since the early 1990s, in terms of erosion of their status as top FDI destinations in the developing world. To a large 
extent, the FDI competition from an emerging China induced the adoption of AFTA agreement in January 1992.

Table 2. FDi flows in Selected East Asian EConomies, from 1991 to 2006

\begin{tabular}{c|c|c|c|c|c|c|c|c}
\hline $\begin{array}{c}\text { Selected } \\
\text { East Asian } \\
\text { Economies }\end{array}$ & $\begin{array}{c}1991-1996 \\
\text { (Annual } \\
\text { Average) }\end{array}$ & 1997 & 1998 & 1999 & 2000 & 2002 & 2004 & 2006 \\
\hline Brunei & 210 & 702 & 573 & 748 & 549 & 1,035 & 334 & 434 \\
\hline Indonesia & 2,985 & 4,678 & -356 & $-2,745$ & $-4,450$ & $-1,523$ & 1,896 & 5,556 \\
\hline Malaysia & 5,436 & 6,323 & 2,714 & 3,895 & 3,788 & 3,203 & 4,624 & 6,060 \\
\hline Philippines & 1,226 & 1,261 & 1,718 & 1,725 & 1,345 & 1,111 & 688 & 2,345 \\
\hline Singapore & 6,856 & 13,533 & 7,594 & 13,245 & 12,464 & 7,655 & 19,828 & 24,207 \\
\hline Thailand & 1,964 & 3,882 & 7,491 & 6,091 & 3,350 & 1,068 & 5,862 & 9,751 \\
\hline Vietnam & 1,217 & 2,587 & 1,700 & 1,484 & 1,289 & 1,200 & 1,610 & 2,315 \\
\hline Lao PDR & 53 & 86 & 45 & 52 & 34 & 25 & 17 & 187 \\
\hline Myanmar & 256 & 879 & 684 & 304 & 208 & 129 & 251 & 143 \\
\hline Cambodia & 120 & 168 & 243 & 230 & 149 & 54 & 131 & 483 \\
\hline Southeast Asia & 20,323 & 34,099 & 22,406 & 25,029 & 18,726 & 13,957 & 35,245 & 51,483 \\
\hline China & 25,476 & 44,337 & 43,751 & 40,319 & 40,772 & 52,700 & 60,630 & 69,468 \\
\hline South Korea & 1,234 & 2,844 & 5,412 & 9,333 & 9,283 & 1,972 & 8,960 & 4,950 \\
\hline Taiwan & 1,311 & 2,248 & 222 & 2,926 & 4,928 & 1,445 & 1,898 & 7,424 \\
\hline
\end{tabular}

SOURCE: Data retrieved and calculated from World Investment Reports (UNCTAD, 2003: 251 \& UNCTAD, 2007: 253).

In terms of regional competition for FDI, two important factors explain the drastic change of comparative advantage in investment patterns between China and the ASEAN: first, China's huge market potential motivated Western firms' attempts to internalize technological advantages; secondly, the country's vast/cheap labor forces and expanding skills base encouraged multinational corporations (MNCs) seeking labor-intensive production to invest. More specifically, the principal FDI drivers in China are connected to its large domestic middle-class markets -currently about US\$ 1 trillion. Moreover, large supplies of labor supplemented by improving industrial capability stimulated domestic and foreign investment (Winters \& Yusuf, 2006: 18). While the first driver creates a base for industries with large economies of scale, the second tends to keep wages down and helps maintain labor-intensive industries. The combination of all these features leads to the emergence of certain mid-tech and high-tech sectors, such as automobiles, electronics, domestic appliances, pharmaceuticals and engineering. In this perspective, the Chinese authorities have facilitated local-market oriented FDI inflows 
by adopting a technology import programme which encouraged technology transfer and has been implemented within the framework of a strict and selected industrial policy (Andreosso-O'Callaghan \& Qian, 1999: 139).

As a result, patterns of comparative advantage and competitiveness have dramatically changed in East Asia, mostly at the expense of the core ASEAN countries from where transnational companies (TNCs) moved parts factories to China (Winters \& Yusuf, 2006: 23). Foreign firms, especially those from the EU specialized in motor vehicles, chemicals and energy, involved high-technology transfer either to their own joint ventures or with their Chinese counterparts. Aside from heavy flows of FDI, another important event established China's position as regional economic power at the expense of the ASEAN economies.

\section{(2) The 1997 Asian Financial Crisis}

Over the last two decades, FDI inflows have been a major driving force and played a determining role in the development of major ASEAN economies. Yet, the outbreak of the Asian financial crisis in 1997 put their economic performance at hard test. Indeed, the regional dimension of the crisis' effects exposed many East Asian countries, especially the core ASEAN states, to a sharp depreciation in their currencies and, consequently, led to a massive withdrawal of short-term foreign capital. While the ASEAN economies were severely affected by this unprecedented event, the top Beijing leaders pledged themselves to maintain a stable renminbi (RMB), encouraged by the rapid economic growth of China and the increasing volume of FDI flowing into it in the late $1990 \mathrm{~s}$. This commitment received considerable praise from the international community, which acknowledged the RMB as a "pillar of stability" in the region ( $\mathrm{Li}, 2000: 938$ ) and consequently, recognizing the leading role China has taken in promoting economic stability and openness in Asia (Yang, 2001: 28).

As a result, the regional financial crisis provided Beijing with an exceptional opportunity to assert itself as the top recipient of FDI in East Asia and strengthened its regional economic leadership status. A closer examination of the data in Table 2 reveals that during the crisis period (1997-1998), China has roughly maintained its performance (from US\$ 44,337 billion to US\$ 43,751 billion), while FDI flows into Southeast Asia has drastically decreased from US\$34,099 billion to US\$22,406 billion. The decline in the FDI package was particularly evident in the core ASEAN economies, notably Singapore, Malaysia and Indonesia.

In light of the rapid change of comparative advantage in FDI patterns within the region, there was a growing perception among Southeast Asian leaders that the expanding Chinese economy would divert FDI flows away from the ASEAN and further towards China (Yoshimatsu, 2007: 231). Under the circumstances, it is expedient that the 'Statement on Bold Measures' issued at their $6^{\text {th }}$ Summit held in December 1998, which revised and spelt out urgent measures to implement 
both the AFTA and ASEAN Investment Area projects, was designed not only to cope with the drastic effects of the crisis, but more importantly to balance the regional economic ascent of Beijing. The regional economic competition between China and its Southeast Asian neighbors has become more perceptible since its accession to the WTO.

\section{(3) China's accession into the WTO}

After 15 years of marathon talks, the final deal for China's World Trade Organization (WTO) membership was concluded and China became a WTO member on December $11,{ }^{\text {th }} 2001$. In the world of economics, membership in the WTO clearly marks a milestone in China's integration into the regional and global economic order, in that this emerging giant currently stands as the center of production networks spanning throughout Southeast and East Asia, but this also increases its capacity to absorb flows of savings/investment and raw materials, while asserting its presence on global markets of manufactured goods. A priori, heavy investment flows into China, induced by its rapid economic growth, offers the ASEAN economies unprecedented opportunities to supply parts and components to plants located in the neighboring emerging giant or vice-versa, with China supplying parts and components to plants in Southeast Asian countries (Roland-Host \& Weiss, 2005: 27; Winters \& Yusuf, 2006: 33).

However, Beijing's increasing absorption of FDI, boosted by its accession to the WTO, is likely to squeeze the ASEAN economies from global investment opportunities, as clearly reflected in Table 2, but more importantly expose them to tougher competition in the final destinations of manufactured goods. Besides, considering global markets and comparing the trade patterns of China and target countries, Steven \& Kennan (2006) correctly observe that countries with export patterns similar to China's are likely to suffer losses as China grows. Recent surveys and data suggest that Beijing's strong export growth has largely eroded the ASEAN's established positions in third-country markets and induced losses of market share in the products lines where the latter is most specialized. Roland-Host \& Weiss (2005: 26), for instance, observed that absolute export declines were found in primary products and engineering to the USA and in primary products, resourced-based manufactures, textiles, garments and footwear to Japan. Eroding their shares on the world markets, China's exponential export growth also exposes the ASEAN economies to fierce competition in their own domestic markets with a range of products sold at cheaper prices.

The growing competition from China in FDI and trade shares patterns in the new millennium undoubtedly provided incentives for ASEAN leaders to accelerate and complete the AFTA project as soon as possible, and adopt the Bali Concord II in 2003, designed, among others, (i) to remove tariff and non-tariff barriers to free flow of business persons, goods, services, skilled labor and talents 
by 2010, and ensure a freer flow of capital, (ii) to transform, AFTA into ASEAN Economic Community (AEC) by the revised target year of 2015, etc. In parallel, the realization of the AEC will provide the ASEAN economies with a strategic means of coping with potential economic challenges posed by the growing presence of China on the world markets, in that it will further the conclusion of single pattern bilateral FTAs that they have been negotiating with their major trading partners, ${ }^{18}$ thereby increasing trade opportunities and investment flows.

In this view, it is important to mention that the recent China-ASEAN FTA, proposed by China in late 2000 and formally endorsed by the ASEAN in November 2001, should be analyzed in terms of the promotion of economic interdependence and insurance against the predation of conflicts in a region where various Asian dyadic rivalries remain unsolved. As Nesadurai (2005: 165) correctly noted, it would have been difficult to reject the Chinese proposal, given the ASEAN countries' desire to engage with China on political and security issues. The next section examines the case of the UEMOA Common Market.

\section{THE UEMOA COMMON MARKET}

\section{The UEMOA and UEMOA CM Proposals}

The UEMOA is a regional grouping of eight countries ${ }^{19}$ created in January 1994. Resulting from the merger of the existing West African Monetary Union (created in 1962), and West African Economic Community (created in 1973), the creation of the UEMOA aims to achieve five fundamental objectives: ${ }^{20}$ (i) boost the competitiveness of the member states in an open market and secured environment; (ii) achieve convergence between policy and macro-economic policy indicators; (iii) create a Common Market (CM) between the member States based on a common external tariff, a common trade policy, free movement of persons, goods, services, capitals, and right of settlement for people exerting a liberal or wage activity; (iv) coordinate national sectoral policies through the implementation of common programmes and policies; (v) align the member countries' budgetary and fiscal regimes as far as possible to the perfect operationalization of the CM.

When closely analyzed, all these objectives converge towards the realization of one unique objective: the creation of an economic union ${ }^{21}$ that will be progressively realized through the establishment of a regional $\mathrm{CM}$ as its key-vehicle. The $\mathrm{CM}$ is a Customs Union within which, the free movement of the factors of production, namely labor, capital and enterprise is added to the free movement of goods. In order to achieve the main objectives of the Union through the establishment of a regional CM, the member States defined and adopted a series of regional mechanisms and policies. General provisions on the Union's CM aimed at progressively realizing the following objectives (article 76, UEMOA 
Treaty): (i) suppression of customs duties, quantitative restrictions on import and export, taxes generating equivalent effects or all other measures generating similar effects on exchanges between member countries, susceptible of affecting those transactions, without infringing the Union's rule of origin, which will be specified by way of additional protocol (art. 77-81); (ii) agreement on a common external tariff (CET) (art. 82-86); (iii) institution of common rules of competition applicable to States and private companies, as well as to government aids (art. 88-90); (iv) implementation of principles promoting free movement of persons, freedom to establish and provide services, as well as those inherent to free movement of capital, which are indispensable for the development of the regional financial market (art. 91 \& 92); and (v) harmonization and mutual acceptance of technical norms, as well as homologation and certification procedures related to the control of their implementation.

In order to oversee an efficient operationalization of these programmes, the member governments endowed the Union with an institutional architecture unfolded through four groups of bodies:22 (i) organs of direction embodied by the Authority of Heads of State and Government, the Council of Ministers, and the UEMOA Commission; (ii) organs of control represented by the Court of Justice, the Audit Office and the Inter-parliamentary Committee; (iii) advisory organs embodied by the Regional Consular Chamber; (iv) and autonomous specialized institutions represented by the Central Bank of West African States (BCEAO), the West African Development Bank (BOAD) and the Regional Exchange Stock.

A close analysis of the UEMOA Common Market proposals, taken together with the basic objectives defined in the UEMOA Treaty, suggests a serious ambition behind West African Francophone leaders' decision to set up a single regional bloc resting on a legal and institutional basis. Yet, the realization of this important regional project will mostly depend on the level of commitment in its implementation process.

\section{The process of the UEMOA CM implementation}

The process has been marked by a number of commitments that may be assessed in two dimensions: (i) the adoption of appropriate programmes, policies and regulations to back and accelerate the realization of the project; and (ii) the expansion and consolidation of the initial scope to speed up the establishment of this single regional market.

\section{(1) The acceleration of the UEMOA CM project}

The programmes, policies and regulations adopted by the UEMOA members to start the realization of the $\mathrm{CM}$ fall into three categories: (i) establishment 
of the Customs Union; (ii) adoption of a common trade policy and rules of competition; and (iii) free movement of persons, and services, and the right of residence.

The establishment of a Customs Union induces the progressive removal of tariff barriers, the adoption of a preferential tariff regime, a common external tariff, as well as a mechanism of compensation of customs receipts depreciations. The transitory preferential tariff regime was adopted on May $10^{\text {th }} 1996$ at the $1^{\text {st }}$ Session of Assembly of Heads of State and Government. ${ }^{23}$ Entered into effect on July $1^{\text {st }} 1996$, it aims at increasing the number of products exchanged within the Union, and is designed to progressively lower tariff barriers as follows: (i) from July $1^{\text {st }}$ 1996: immediate suppression of all non-tariff barriers impeding exchanges between the Union's member States; free movement of unprocessed and traditional handicraft goods between the member States, free from customs duties and taxes; reduction of customs duties and taxes for non recognized originating industrial goods to 5\%; (ii) from July $1^{\text {st }} 1996$ to June $30^{\text {th }} 1997$ : reduction of taxes and customs duties for recognized originating industrial goods covered by the Community Preferential Tax (TPC) to 30\%; (iii) from July $1^{\text {st }} 1997$ to December $31^{\text {st }}$ 1998: Reduction of customs duties and taxes for recognized originating industrial goods to 60\%; (iv) from January $1^{\text {st }} 1999$ to December $31^{\text {st }}$ 1999: Reduction of customs duties for recognized originating industrial goods to $80 \%$; (v) from January $1^{\text {st }} 2000$ : Integral tariff disarmament to $100 \%$ for recognized originating industrial goods.

By January $1^{\text {st }} 2000$, the integral tariff disarmament was effective for those products (UEMOA Annual Report, 2000: 18). Then, a new transitory period started, which was completed on December $31^{\text {st }} 2005$. This term was designed to transfer the exclusive competence regarding the community rules of origin to the member States. As of that term, 2600 products manufactured within the Union were admitted as originating industrial goods and registered in a unique document. This tariff disarmament within the Union was sustained by the Common External Tariff (CET) adopted in 1997 and entered into force in 2000.

In order to provide the regional liberalization programmes against contingencies inherent to customs receipts depreciations, the member governments adopted the Additional Act No 06/99 on December $8^{\text {th }} 1998$, instituting a mechanism of financial compensation within the Union (Art. 3 \& 7, Additional Act 06/99). This mechanism is scheduled to be implemented for a time-limit of six years, from January $1^{\text {st }} 2000$ to December $31^{\text {st }} 2005$. To complete the establishment of the Common Market, they adopted a common trade policy designed to promote intra-regional trade, to ensure the competitiveness of products originating from the Union on the world markets, to improve production capacities within the Union, and to protect the Union's production networks against dumping practices and third-country subventions. To this end, the Union evolved two strategies: (i) negotiations of bilateral and multilateral trade agreements with third parties; and (ii) the community policy of competition 24 likely to make the UEMOA 
bloc not simply a promotion area for local enterprises but also a secured and attractive zone for foreign investors.

In the same logic, to speed up the establishment a regional competitive and integrative Common Market, a number of appropriate regulations on the free movement of persons, capital, services, as well as the right of residence, were adopted at the $9^{\text {th }}$ Summit of Heads of State and government, held in Niamey (Niger) on March $30^{\text {th }} 2005$ (UEMOA Annual Report, 2005: 24). Prior to these measures, and with a view to increase capital flows into the Union, a Regional Financial Market ${ }^{25}$ project was adopted and assigned three objectives: (i) increase the savings rate by diversifying financial products conducive to creating conditions that generate domestic saving and foreign capital; (ii) strengthen the financial structure of enterprises likely to generate capital over the long term; and (iii) reduce financial intermediation costs by directly tying capital supply to demand.

In sum, since its inception, a number of programmes, policies and regulations have been adopted by the UEMOA members to speed up the realization of the Common Market. In parallel, this regional liberalization package was expanded to other strategic sectors, while the UEMOA 2015 Vision was recently defined to speed up and consolidate the implementation of the UEMOA CM project.

\section{(2) Expansion and consolidation of the UEMOA CM project}

The expansion of the UEMOA CM project was adopted by the Authority of Heads of State and Government of the Union on May $10^{\text {th }} 1996$, through the Additional Protocol No II ${ }^{26}$ related to the sectoral policies of the UEMOA. Seven sectors were then identified by the member States as important to be promoted by initiating and strengthening efficient and sustainable common policies, with a view to speed up the economic integration and achieve their efforts to set up a veritable regional single bloc: development of human resources, transports and telecommunications, environment, agriculture, energy, mining, and regional planning.

The Regional Planning Policy ${ }^{27}$ supported these common sectoral policies aimed at building a stronger, more interdependent, more attractive and competitive Union, consistent with a regional market within which the member countries optimize their comparative advantages. To this end, four major programmes of actions were defined: (i) promotion of the Community regional planning in member States' public policies; (ii) acceleration of the concerted realization of major community infrastructures and equipments, as well as a regional urban framework; (iii) spatial orientation of the development of the UEMOA's potentialities, to reinforce the member States' complementarity, competitiveness and better insertion in the regional and world economy; and (iv) development of community interdependence and reinforcement of social cohesion (art.6 Additional Act No 03/2004). A closer examination of the programmes of actions listed above reveals the serious ambition underlying the member governments to accelerate the realiza- 
tion of the single regional competitive market. These programmes perfectly reflect the UEMOA 2015 Vision.

The adoption of the UEMOA Vision 2015 responds to the necessity to speed up the realization of a unified Common Market, likely to assert itself as "a dynamic and competitive regional economy which successfully integrates itself into the African and global economies."28 This new vision originates from the solemn Declaration entitled "Impel a new dynamics with the regional integration process" 29 made in January 2004 in Niamey (Niger) at the $8^{\text {th }}$ Summit of Heads of States and Governments, the contents of which may be summarized as follows: "Making UEMOA a unified and open space for the benefit of an interdependent population." In short, the new vision provides the Union with the basis for a new approach to organize the production, the movement of factors of production, goods, services and capital within the region.

In sum, the UEMOA CM process has been marked by the member governments' commitment to accelerate its implementation process. More importantly, its initial scope has been extended to include common policies adopted in strategic sectors; all these programmes and policies incorporated in the UEMOA Vision 1015 aimed at speeding up the establishment of a single regional and competitive bloc. But fundamentally, how has regional economic and leadership competition from Nigeria as an emerging neighboring power been influencing and shaping the programmes and policies adopted and implemented by the UEMOA member countries?

\section{The UEMOA CM Process in the Context of Regional Economic Competition from Nigeria}

A number of factors stemming from the global systemic level have influenced the implementation of the UEMOA CM process, as explained in the literature review. However, other important ones deriving from regional level merit particular attention. Indeed, the Federal Republic of Nigeria, since the early 1990s, has been identified as one of the leading destinations for FDI in Africa, boosted by its transition to democratization process in 1999, and the National Economic Empowerment and Development Strategy (NEEDS) adopted in 2003. All these strategic advantages could not fail to worry its West African Francophone neighbors, always opposed to its emergence as regional "paymaster" (Bach, 1983: 605-623; Inegbedion, 1994: 221).

\section{(1) Evolution of FDI inflows to Nigeria}

The evolution of FDI flows into the West African subregion during the 1990s has largely benefited Nigeria. The data in Table 3, which records the FDI movements in selected West African economies, perfectly reflect the position of Nigeria as the top recipient of foreign investment flowing into the subregion since the early 1990 s. A closer analysis of this data suggests that during the 
period 1991-1996, average annual flows into Nigeria amounted to US\$1,264 million, while the whole UEMOA zone received only US\$287 million. However, the launching of the UEMOA CM process in July 1996 by the member States made it possible to narrow the huge gap from 1997 to 2000. Undoubtedly, growing FDI competition from the neighboring giant, to a large extent, induced West African Francophone leaders to initiate and accelerate the creation of a regional competitive and balancing bloc within the subregion in 1994.

Table 3. FDi flows in Selected West African Economies, from 1991 to 2006

\begin{tabular}{c|c|c|c|c|c|c|c|c}
\hline $\begin{array}{c}\text { Selected West } \\
\text { African } \\
\text { Economies }\end{array}$ & $\begin{array}{c}1991-1996 \\
\text { (Annual } \\
\text { Average) }\end{array}$ & 1997 & 1998 & 1999 & 2000 & 2002 & 2004 & 2006 \\
\hline Benin & 42 & 26 & 35 & 61 & 60 & 41 & 64 & 63 \\
\hline Burkina & 9 & 13 & 10 & 13 & 23 & 8 & 14 & 26 \\
\hline Cote d'Ivoire & 158 & 450 & 416 & 381 & 235 & 223 & 283 & 253 \\
\hline Guinea Bissau & 2 & 11 & 4 & 9 & 1 & 1 & 2 & 42 \\
\hline Mali & 29 & 74 & 36 & 51 & 83 & 102 & 101 & 185 \\
\hline Niger & 16 & 25 & 9 & - & 9 & 8 & 20 & 20 \\
\hline Senegal & 20 & 176 & 71 & 136 & 63 & 93 & 77 & 58 \\
\hline Togo & 11 & 23 & 42 & 40 & 42 & 75 & 59 & 57 \\
\hline UEMOA Zone & 287 & 798 & 623 & 691 & 516 & 551 & 620 & 706 \\
\hline Nigeria & 1,264 & 1,539 & 1,051 & 1,005 & 930 & 1,281 & 2,127 & 5,445 \\
\hline Guinea & 14 & 17 & 18 & 63 & 10 & 30 & 96 & 106 \\
\hline Ghana & 105 & 82 & 56 & 267 & 115 & 50 & 139 & 435 \\
\hline West Africa & - & - & - & - & - & - & 3,743 & 6,841 \\
\hline
\end{tabular}

SOURCE: Data retrieved and calculated from World Investment Reports.

(UNCTAD, 2003: 249-250 \& UNCTAD, 2007: 251-252).

NOTE: $(-)=$ non available.

Despite this commitment, the data in Table 3 suggest that fierce competition from Nigeria has surfaced in 2002 and, since then, its net advantage in attracting FDI flows into the region has spectacularly increased, reaching $80 \%$ in 2006 at the expense of its neighbors. If in part, the decline in the UEMOA's performance to attract FDI may be ascribed to the political crisis in Cote d'Ivoire affecting the region since 2002, the country considered as the economic locomotive within UEMOA bloc, the recent diversion of FDI volume flowing into West Africa to Nigeria is boosted by two important factors: (i) the positive political developments occurring in this giant since May $29^{\text {th }} 1999$, when democracy replaced the ballet of military governments; and (ii) the increasing importance of African oil that spawned investment competition between external powers. 
The first factor was determinant in that it created a secured environment by bringing both greater economic stability and growth, and much more liberal conditions to attract foreign investors to the country. In a bid to take advantage of this, the Nigerian authorities enacted a series of regulations and policies including a more relaxed taxing system, the creation of the Nigerian Investment Promotion Commission (NIPC), the privatization of all the ailing public enterprises, and the creation of the Bank of Industry and the Small and Medium Industries Equity Investment Scheme (SMIEIS). The immediate effect of these measures was countless FDI in-roads into the country, which cut across all sectors of the economy, notably information and communication technology, oil and gas industry, capital market, agriculture, and solid minerals. 30

This position is supported by recent data on investment into Nigeria between 1999 and 2002. In accordance with a paper ${ }^{31}$ presented by the Director of Nigerian Investment Promotion Commission at an international conference organized by MOFA (Japan), the level of investment commitment by 143 companies registered at the NPIC was US\$ 466.4 million; re-investment by major MNCs amounted to over US\$ 2 billion; projected employment generation was over 20,959; total capital imported for investment purpose was US\$ 506.2 million; capital market capitalization saw a 156\% change between 1999 and 2002; annual return on investment in capital market was $105 \%$, making the Nigerian stock market one of the most profitable in the world; and foreign investment inflows from the privatization program was US\$ 470.3 million in 2002.

The investment policy enacted by Nigeria, in part, explains the recent FDI inflows to this country. Yet, another important factor is connected to the resurgence of interest in African oil by Western powers and emerging Asian economies. Indeed, since the early 2000s, Africa's hydrocarbons have suddenly become an increasingly attractive resource for external economic powers and, thereby, the source of competition mostly between Washington and Beijing. The current international context of the crude oil market was subjected not only to the political risks and uncertainties in other oil-producing regions (Iraq and Iran), but more importantly to the rising energy demands of China and India, the approaching maturity of major oil fields, as well as the shortage of world stocks, explain this resurgence of interest in the continent (Joannidis, 2006; Wolfe, 2006). In this tight competition, where FDI is used as the appropriate spur to prospect and negotiate African's hydrocarbons markets, Nigeria is by far favored as the top African producer and the sixth world exporter, with a production capacity of up to "2.51 million barrels per day in 2004." 32 In July 2005, China signed a US\$ 800 million crude oil agreement with Nigeria, and was considering US\$ 7 billion worth of investments in Nigeria (Wolfe, 2006). This investment line was lengthened to an agreement to construct a railway network in Nigeria, at the recent Beijing Summit on China-Africa Cooperation held in November 2006 (Samson, 2006). 
The positive political developments in this giant, taken together with its investment potentials, explain its position as the top recipient of FDI flowing into West Africa, at the expense of its neighbors. Under the circumstances, the surrounding countries cannot divert such trend, unless they initiate and adopt consequent strategic reforms. This logic induced the UEMOA governments to speed up the CM implementation process, to expand the initial liberalization package to some strategic sectors. The balancing logic perfectly reflects the Regional Planning Policy supporting these common sectoral policies, which aims at building a stronger Union, which is more interdependent, more attractive and competitive, consistent with a regional market within which each member State optimizes, in complementarity, its comparative advantages. Besides regional FDI competition, another important factor explains the UEMOA leaders' commitment to consolidate their regional integration scheme.

\section{(2) The adoption of the National Economic Empowerment and Development Strategy (NEEDS)}

Encouraged by the positive political developments occurring in the country, the Nigerian authorities adopted the National Economic Empowerment and Development Strategy (NEEDS) in 2003, designed "to build a truly great African democratic country, politically unified, integrated and stable, economically prosperous, socially organized, with equal opportunity for all, and responsible from all, to become the catalyst of African Renaissance, and making adequate all embracing contributions, subregionally, regionally and globally." 33 This strategy is supported by the project "Nigeria: the Heart of Africa,"34 a cohesive information programme destined to enhance the international perception of Nigeria and the value placed on its products, to promote its economic advancement through sustainable programmes, to showcase and buttress Nigeria's pivotal role in Africa's development, etc.

Undoubtedly, through the NEEDS, Nigeria seeks to deepen the integration of its economy with the rest of the world and, thereby, maximize the benefits of strategic integration. To achieve this ambitious programme, the federal authorities identified, among others, two strategic instruments: "regional integration and trade policies." 35 The NEEDS provisions on regional integration asserts Nigeria's "commitment to the full and complete implementation of the free trade zone agreements of the Economic Community of West African States (ECOWAS), the creation of a single monetary zone, and the unification of West Africa into a common customs territory." To this end, the strategic document calls on the ECOWAS member governments to align their national policies towards (i) the adoption of a common trade and competition policy in West Africa, (ii) the adoption of a common currency in West Africa under the West African Monetary Zone Protocol, (iii) the removal of all non-tariff barriers to 
trade, and (iv) the introduction of a common external tariff regime in West Africa."

With regard to trade policies, Nigerian policy-makers defined as strategic measures "to reduce drastically uncertainties and unpredictability impeding the trade regime, to harmonize trade practices with those of other ECOWAS countries (and thus facilitate the Free Trade Area within the region), to respect Nigeria's obligations under the multilateral and regional trading system, and to create a conducive and competitive environment in which Nigerian businesses can flourish and compete in the global and regional economy." The goal underlying this policy, as specified the NEEDS, is "to lay a solid foundation for fully exploiting Nigeria's potential in international trade and helping it become the gateway to West and Central Africa."

Apparently, these strategies seem relevant and opportune to speed up the regional integration process in West Africa. Nonetheless, behind Nigeria's commitment to move ahead with the full and complete implementation of the ECOWAS free trade zone, the creation of a single monetary zone, and the unification of West Africa into a common customs territory, lays a hegemonic aspiration for regional economic leadership, as clearly indicated by the strategic goal of its trade policies. In terms of regional potential, it is important to recall that, within the ECOWAS context, which encompasses all the UEMOA member States, Nigeria accounts for $45 \%$ of regional GDP, $66 \%$ of total exports, and more than half (140 millions of people in 2006) ${ }^{36}$ of the population of the subregion (ECOWAS Annual Report, 2002: 8). Bazika \& Dirat (2003) correctly noted that with its demographic and economic potentials, Nigeria should lead the regional integration process in West Africa, though this role is contested by the surrounding countries.

The context of the resurgence of Nigeria's aspiration for regional leadership, taken together with its regional competition in terms of FDI in the new millennium, has influenced the final Communiqués ${ }^{37}$ released by the UEMOA Authority of Heads of State and Government on January $10^{\text {th }} 2004$, urging the Union's institutions (BCEAO, BOAD and the UEMOA Commission) to finalize and implement the Regional Economic Programme (backbone of the UEMOA Vision 2015), indispensable to impel a new dynamic with the construction of the UEMOA single market. The next section draws an analysis of the AFTA and the UEMOA CM processes.

\section{ANALYSIS OF THE TWO CASE STUDIES}

The adoption of the AFTA and the UEMOA CM projects, followed by their respective implementation processes, have strongly been influenced by economic leadership competition from emerging neighboring powers, namely China and 
Nigeria respectively. If the emergence of powerful trading blocs was perceived in the early 1990s as source of virtual economic threat, the geo-economic potentials of China and Nigeria, taken together with their regional ambition and deeper economic reforms in the post-Cold War era, posed a greater challenge of economic survival to the ASEAN and UEMOA economies respectively.

Within this regional economic competitive environment, changes in FDI patterns of comparative advantage merit particular attention. Indeed, an analysis of recent investment trends in East Asia suggests that from 1992, and throughout the rest of the 1990s, the comparative advantage of FDI has dramatically shifted from Southeast Asian core countries to China, with nearly double records of FDI flowing annually into the latter Table 1 . The net difference in FDI patterns, already perceptible in the late 1990s, has dramatically increased in the new millennium with China's accession to the WTO at the expense of ASEAN economies Table 2. Likewise, in West Africa, evidence in Table 3 suggests that during the period 1991-1996, while annual average flows into Nigeria amounted to US\$ 1,264 million, the whole UEMOA zone received only US\$287 million. After declining in the late 1990s, fierce competition from Nigeria has resurfaced in the new millennium, so that the latter's comparative advantage in attracting FDI flows into the West African region has increased spectacularly and reached $80 \%$ in 2006.

A number of motives explain the diversion and concentration of FDI into China and Nigeria since the early 1990s, at the expense of the ASEAN and UEMOA countries respectively. Thereupon, the literature on FDI in the globalization era identifies four different factors. 38

(i) Market-seeking investments to access new markets that are attractive due to their size, growth or a combination of both; (ii) Efficiency-seeking investments that aim at taking advantage of cost-efficient production conditions, namely the cost and production levels of the local workforce, the cost and quality of infrastructure services (transport, telecommunication) and the administrative cost of doing business; (iii) Natural-resources seeking investments to exploit endowments of natural resources; and (iv) Strategic-asset seeking investments oriented towards man-made assets, as embodied in a highly-qualified and specialized workforce, brand names and images, shares in particular markets, etc.

A closer examination of China's and Nigeria's investment environment suggests that while the former, with its 1.3 billion population covers a huge domestic market, and offers an expanding skills base and a vast/cheap labor force indispensable to MNCs seeking advantages in labor-intensive production, the latter stands as the top African oil producer and world's the sixth largest exporter, and represents 
the most populous African country (140 million people), covering the widest internal market and offering the most highly trained work forces in Africa. 39 To capitalize these investment potentials, both giants have been committed, since the last decade, to advanced and deepened economic reforms in deregulation of investment and trade, sustained by the restoration of democracy in Nigeria in 1999 and China's accession into the WTO in 2001.

The cumulative effects of these potentials and reforms have undoubtedly galvanized both giants' ascent for regional economic leadership and strengthened their competitiveness in terms of market-seeking investment, efficiency-seeking investment, strategic-asset seeking investment, and particularly that of Nigeria regarding natural-resources seeking investment. As a result, the evolution of comparative advantages in FDI patterns at regional level has drastically changed at the expense of their weaker neighboring economies, notably those in Southeast Asia and West Africa, as clearly shown in Tables 1, 2 and 3. Aside from FDI competition, the ASEAN and UEMOA countries are exposed to fierce competition of trade shares, not only in their own domestic markets but also in regional and international markets, as highlighted by the case of the ASEAN exporting countries.

As one may notice, being located in the same geographic area as such emerging regional economic powers with potential assets to compete for production locations, trade shares, stock market capital and investment, is likely to keep the weaker neighboring countries from getting international visibility in the globalizing world, and jeopardize their economic survival, unless they create a single regional competitive bloc, likely to counterbalance the giants' regional economic weight. This logic perfectly reflects the decision by the ASEAN and UEMOA leaders to create the AFTA (to be transformed into the AEC) and the UEMOA CM within East Asian and West African regions respectively.

The different programmes and policies adopted during the implementation process of their respective regional schemes converge towards the same objective: establish a regional single bloc likely to cope with growing economic competition from an emerging China and Nigeria as soon as possible. Indeed, since individually they cannot compete with their neighboring giants, the rapid integration of their narrow domestic markets remains the strategic alternative to get regional and international visibility. To this end, not only is timing important to be considered regarding the liberalization process, but also priority should be given to strategic sectors of cooperation likely to further and speed up the integration process. More importantly, institutional mechanisms need to be created and strengthened to "coordinate rules, regulations, and policies, and eventually help to ease distributional tensions among the member states" (Mattli, 1999: 14).

Concerning the timing, efforts have been perceptible within both blocs to speed up the liberalization process by lowering tariffs and removing other barriers that segment markets and impede the free flow of goods, services and factors of production. Indeed, while the UEMOA governments' commitment to complete 
the transitory preferential tariffs regime within four years (1996-2000) was effective by January 2000, the ASEAN governments revised the original target year of 2008 to complete the AFTA to 2003. The new target horizon of 2015, recently adopted by both regional governments to consolidate their respective integration schemes, underscores their commitment to accelerate the establishment of single and competitive market, indispensable to cope with the growing regional competition from their neighboring giants.

The expansion of both the AFTA and the UEMOA CM initial liberalization programmes to other strategic sectors responds to the same imperatives. In terms of institutional architecture and mechanisms, the UEMOA bloc is endowed with supranational institutions to coordinate rules, regulations, and policies, and settle disputes likely to come up among the member States during the implementation process. The most active are the UEMOA Commission, the Court of Justice, BCEAO and BOAD. If the ASEAN governments had been reluctant for decades to endow their regional bloc with supranational institutions and binding agreements, the potential economic challenges posed by the rising China in the new millennium, finally induced them to shift from their traditional 'ASEAN way.' The imperious necessity to coordinate rules, regulations, and policies, indispensable to establish the AEC by the target horizon of 2015, explain their decision to strengthen the existing DSM in 2003, as well as the adoption of the ASEAN Charter in November 2007.

\section{CONCLUSION}

This article took a particular look at one of the main dynamics driving the resurgence of interest in regionalism in Southeast Asia and West Africa since the early 1990s. Under the AFTA and UEMOA CM schemes, the ASEAN and West African Francophone leaders respectively, have embarked on market liberalization at higher level over the last decade. Within both regional blocs, the member governments made significant efforts to accelerate the establishment of a single and competitive market, by lowering tariff and non-tariff barriers, promoting intra-regional trade and expanding the liberalization programmes to strategic sectors.

The decision to set up the AFTA and UEMOA CM, a priori, was triggered by the fear of being economically marginalized in a globalizing world characterized by (i) the growing movement towards the formation of an inward-looking trade bloc in North America, (ii) the consolidating process of European economic integration through the Maastricht Treaty, (iii) the potential investment diversion to emerging trading blocs, and (iv) the growing perception of protectionism in the European and U.S. markets. However, the ASEAN and the UEMOA leaders' perception of vulnerability and marginalization in the current context of the post-Cold War 'marketization' was spurred by their emerging neighboring giants 
-China and Nigeria-of which deeper economic reforms and potential to compete for production locations, market shares, stock markets capital and FDI are likely to keep them from getting international visibility in the globalization era.

The growing economic competition from these neighboring giants in the new millennium, heightened by the rapid change of comparative advantages in FDI patterns, induced the ASEAN and UEMOA governments to define a new vision to back their integration process. While the former agreed in 2003 to the AEC envisioned as a single regional market and production base in Southeast Asia establish by the revised target year of 2015, the latter has been committed since 2004 to impel a new dynamics with the regional integration process conducive to set the UEMOA bloc by the target year of 2015 as a unified, open, and competitive space within the West African subregion. In either case, the different programmes adopted and reforms initiated since the early 2000s mostly converge towards the same objectives: cope with the rapid change of comparative advantage in FDI and trade patterns induced by a rising China and Nigeria, and balance the neighboring giant's growing ascent for regional economic leadership.

Provided that the end of the historic confrontation between the United States and the Soviet Union has deeply changed the global political landscape and introduced profound economic reforms in many parts of developing world, where new regional hegemons have been emerging over the last decade, it is useful to apply some implications of this study to regional integration schemes at work there or to erupt in the years/decades ahead. The phenomenon is already evident within the Persian Gulf, where the GCC members have been committed since January $1^{\text {st }}, 2003$ to deeper regional economic integration to strengthen their existing political ties, and to cope with Iran's propensity for regional economic and geopolitical leadership. After the GCC Common Market launched on 2 January 2008, they envision to create a single currency common to the six members of the Council (Rodriguez, 2008) by 2010.

The same phenomenon is likely to be replicated in Latin America when the current economic reforms in Brazil, coupled with this giant's eventual accession to the United Nations Security Council (UNSC) as permanent member, will officially set its status as a regional hegemon. One important factor likely to trigger the formation and consolidation regional politico-economic blocs against the Latin American giant is connected to the contemporary structural change in international politics, characterized by the return of historical culture and identity (Wendt, 1996). Provided that an emerging Brazil is the sole Lusophone country in the region, it is not out of the question that membership within the existing regional blocs, such as Mercosur (Mercado Común del Sur), the Andean Community, and CARICOM (Caribbean Community and Common Market) will be subjected to revision, with balancing or bandwagoning effects. 


\section{REFERENCES}

Andreosso-O'Callaghan, B. and Qian, W. 1999. Technology Transfer: A Mode of Collaboration between the European Union and China. Europe-Asia Studies 51: 123-142.

Bach, D. C. 1983. The politics of West African economic cooperation: CEAO and ECOWAS. The Journal of Modern African Studies 21: 605-623.

Bach, D. C. 2005. The Global Politics of Regionalism: Africa. in M. Farrell, B. Hettne and L. V. Langenhove (Eds). Global Politics of Regionalism: 171-186, London: Pluto Press.

Bakiza, B. J.-C. and Dirat, J.-R. 2003. La crise de l'intégration régionale en Afrique de l'Ouest et du Centre: Quelques Similitudes. Proposition de Thème de Communication (Cotonou), accessed at http://www.codesria.org/Links/conferences/cotonou/diratbazouka.pdf on October 18, 2007.

Bala, J. J. 2003. The Challenges and Opportunities of the Investment Environment in Nigeria. Paper presented at the International Meeting for Investment to Africa, organized by the MOFA (Japan) at Mita (Tokyo), on February $26^{\text {th }}$ 2003, 1-19.

Bowles, P. and MacLean, B. 1996. Understanding trade bloc formation: the case of ASEAN Free Trade Area. Review of International political Economy 3: 319-348.

Bowles, P. 2000. Regionalism and Development after the Global Financial Crises. New Political Economy 5: 433-455.

Buszynski, L. 1997. ASEAN's New Challenges. Pacific Affairs 70: 555-577. Chia, S. Y. 1998. The ASEAN Free Trade Area. The Pacific Review 11: 231-232. Chirathivat, S. 1996. ASEAN Economic Integration with the World through AFTA. in M. Ariff et al. (Eds). AFTA in the Changing International Economy: 21-41, Singapore: Institute of Southeast Asian Studies.

Cooper, S. and Taylor, B. 2003. Power and Regionalism: explaining Regional Cooperation in the Persian Gulf. in F. Laursen (Ed.). Comparative Regional Integration: Theoretical Perspectives: 105-124, London: Ashgate.

Dennis, P. M. and Brown, L. 2003. The ECOWAS: from regional economic organization to regional peacekeeper. in F. Laursen (Ed.). Comparative Regional Integration: theoretical perspectives: 229-249, Hampshire-Burlington: Ashgate.

Denoon, D. B. H. and Colbert, E. 1998. Challenges for the Association of Southeast Asian Nations. Pacific Affairs 71: 505-523.

Gambari, I. A. 1991. Political and Comparative Dimensions of Regional Integration: The Case of ECOWAS. New Jersey \& London: Humanity Press International. Goldstein, A. 2002. The New Regionalism in Sub-Saharan Africa: More than Meet the Eye. OECD Development Centre, Policy Brief 20: 1-34.

Hurell, A. 1995. Regionalism in Theoretical Perspective. in L. Fawcett and 
A. Hurell (Eds.). Regionalism in World Politics: 37-73, Oxford: Oxford University Press.

Inegbedion, J. 1994. ECOMOG in a Comparative Perspective. in J. E. Okolo and T. Shaw (Eds.). The Political Economy of Foreign Policy in ECOWAS: 218-236, New York: St. Martin's Press.

Joannidis, M. 2006. Pourquoi l'OPEP courtise l'Afrique? MFI-HEBDO: Economie Développement, 9 september 2006, accessed at http://www.rfi.fr/fichiers/MFI/ EonomieDeveloppement/1782.asp.

Li, X.-M. 2000. China's Macroeconomic Stabilization Policies Following the Asian Financial Crisis: Success or Failure? Asian Survey 40(6): 938-957.

Low, L. 1996. The ASEAN free trade area. in B. Bijit \& Ch. Findlay (Eds.). Regional integration and the Asia Pacific: 197-206, Sydney: Oxford University Press.

Mattli, W. 1999. The Logic of Regional Integration: Europe and Beyond. Cambridge: Cambridge University Press.

Medhora, R. 1996. Les Leçons de l'UMOA. in R. Lavergne (Ed.). Intégration et Coopération Régionale en Afrique de lOuest: 251-275, Paris: Editions Karthala /Ottawa: CRDI.

Nesadurai, H. E. S. 2003. Globalization, domestic politics and regionalism: the ASEAN Free Trade Area. London \& New York: Routledge.

Nesadurai, H. E. S. 2005. Global Politics of Regionalism: Asia and the Asia-Pacific. in M. Farrell, B. Hettne \& L. V. Langenhove (Eds). Global Politics of Regionalism: 155-170, London: Pluto Press.

Odenthal, L. 2001. FDI in Sub-Saharan Africa. Working Paper 173, OECD Development Centre: 3-54.

Paoloni, M. 1996. The WAEMU, Springboard for Economic Development in West Africa. Study written for the Conference organized by the Club de Bruxelles on 21 \& 22 November 1996, Brussels: Club de Bruxelles.

Ravenhill, J. 1995. Economic cooperation in Southeast Asia: changing incentives. Asian Survey 35: 850-866.

Ravenhill, J. 2006. Is China an Economic Threat to Southeast Asia? Asian Survey 46: 653-674.

Rodriguez, C. 2008. Six Monarchies du Golfe lancent leur marché commun. RFI Actualité, 2 janvier 2008, accessed at http://www.rfi.fr/actufr/articles/097/ article_60995.asp.

Roland-Host, D. and Weiss, J. 2005. People's Republic of China and its Neighbors: Evidence on Regional Trade and Investment Effects. Asian-Pacific Economic Literature 19: 18-35.

Samson, D. 2006. Chine-Afrique: Les Besoins de la Chine rencontrent les Intérêts Africains. RFI Actualité, 6 novembre 2006, accessed at http://www.rfi.fr/ actufr/articles/083/article_47307.asp. 
Stevens, Ch. and Kennan, J. 2006. How to Identify the Impact of China on

Small Countries. Institute of Development Studies Bulletin 37: 33-42.

Tan, J. L. H. 1996. Introductory overview: AFTA in the changing international economy. in M. Ariff et al. (Eds.). AFTA in the Changing International Political Economy: 1-18, Singapore: Institute of Southeast Asian Studies.

Vallejo, D. V. M. 2001. Les Organisations Internationales. Paris: Economica. Walt, S. M. 1987. The Origins of Alliances. New York: Cornell University Press. Wendt, A. 1996. Identity and Structural Change in International Politics. in Y. Lapid and F. Kratochwil, The Return of Culture and Identity in IR Theory: 47-64, London: Lynne Rienner Publishers.

Winters, L. A. and Yusuf, S. 2006. Introduction: Dancing with Giants. in L. A. Winters and S. Yusuf (Eds). Dancing with Giants: China, India and the Global Economy: 1-34, Washington/Singapore: The World Bank/The Institute of Policy Studies.

Wolfe, A. 2006. The increasing Importance of African Oil. Power and Interest News Report, March 20, 2006 accessed at http://pinr.com/report.php?ac=view_ report\&report_id $=460$ \&language_id $=1$.

Yang, D. L. 2001. China in 2001: Economic Liberalization and its Political Discounts. Asian Survey 42: 14-28.

Yoshimatsu, H. 2007. Regional Integration and Business Interests: A Comparative Study of Europe and Southeast Asia. European Journal of East Asia Studies 6: 217-243.

\section{OFFICIAL PUBLICATIONS}

ASEAN Secretariat: Annual Reports \& Publications: www.aseansec.org ECOWAS Secretariat: Annual Reports: http://www.ecowas.int/

Nigerian National Planning Commission, NEEDS, 2004 http://www.nigerianeconomy.com/ UEMOA Commission: Annual Reports and Publications http://www.uemoa.int/ \& www.izf.net

United Nations Conference on Trade and Development, UNCTAD, (1985-2007) World Investment Reports, United Nations, Geneva.

\section{ENDNOTES}

'See A. Goldstein (2002), 'The New Regionalism in Sub-Saharan Africa: More than Meets the Eye', $O E C D$.

${ }^{2}$ SADC Secretariat, "SADC history, evolution and current status" http://www.sadc.int/english/about/history/index.php).

${ }^{3}$ This theory was developed together with the 'balance-of-threat theory' by Stephen Walt in 1987 to provide a realist explanation of regional cooperation in the Persian Gulf, with special emphasis on the Gulf Cooperation Council (GCC) created in 1981 (by Saudi Arabia, Kuwait, Qatar, the United 
Arab Emirates, and Oman) in response to the sudden threat of Iran to the Gulf regimes. According to the balance-of-threat theory, States' alliance behavior is determined by the threat they perceive from other States. Walt contends that States will generally move toward a balance by allying against a perceived threat, although very weak States are more likely to bandwagon with the rising threat in order to protect their own security (S.M. Walt, 1987). This theory was later defended by S. Cooper and B. Taylor (2001: 105-124).

4 http://www.aseansec.org/stat/Table 1.pdf.

5 The Association was created on August $8^{\text {th }}$ 1967. Its founding members are Indonesia, Malaysia, the Philippines, Singapore, and Thailand. Brunei joined them on January $7^{\text {th }}, 1984$. The grouping's membership was expanded by four new members during the $2^{\text {nd }}$ half of the 1990s: Vietnam (July $\left.28^{\text {th }}, 1995\right)$, Lao PDR and Myanmar (July 23, ${ }^{\text {rd }}$ 1997), and Cambodia (April 30, ${ }^{\text {th }}$ 1999).

6 The original target date of 2008 was revised to 10 years by the ASEAN Economic Ministers (AEM) at the September 1994 meeting.

ASEAN Secretariat 1995, The Bangkok Summit Declaratino of 1995, Protocol to Amend the Agreement on Enbancing ASEAN Economic Cooperation; Protocol to Amend the Agreement on the CEPT scheme for the ASEAN Free Trade Area; ASEAN Framework Agreement on Services; ASEAN Framework Agreement on Intellectual Property Cooperation, Bangkok, 15 December 1995.

${ }^{8}$ ASEAN Secretariat 1995, ASEAN Framework Agreement on Intellectual Property Cooperation, Bangkok, 15 December 1995.

9 ASEAN Secretariat 1995, The Bangkok Summit Declaration of 1995, Bangkok, 15 December 1995.

${ }^{10}$ ASEAN Secretariat 1996, Basic Agreement on the ASEAN Industrial Cooperation Scheme, Singapore, 27 April 1996.

1 ASEAN Secretariat 1998, Framework Agreement on ASEAN Investment Area, Manila, 8 October 1998.

12 The 'Statement on Bold Measures' spelt out urgent measures to implement both AFTA and AIA Projects. Details on the Statement accessible at http://www.aseansec.org/8756.htm.

${ }_{13}$ ASEAN Secretariat 1995, ASEAN Framework Agreement on Services, Bangkok, 15 December 1995.

${ }_{14}^{14}$ ASEAN Annual Report, 2005-2006: 9, accessed at http://www.aseansec.org/AR06/Centre-1.pdf.

${ }^{15} \mathrm{http}: / /$ www.aseansec.org/20853.htm.

${ }^{16}$ Ravenhill(2006: 655) came up with similar observations, considering a survey based on World Investment Reports (UNCTAD, 1985-2004).

${ }^{17}$ See Keynote addressed by the Singaporean Prime Minister Goh Chok Tong at the Wef East Asian Economic Summit, on 8 October 2002 in Kuala Lumpur (Malaysia) "Deepening Regional Integration and Cooperatio", ASEAN Secretariat 2003 (http://www.aseansec.org/12321.htm).

${ }^{18} \mathrm{http} / / / \mathrm{www}$.asean.org/13999.htm.

${ }^{19}$ The founding member States of the UEMOA are Benin, Burkina Faso, Cote d'Ivoire, Mali, Niger, Senegal and Togo. Guinea Bissau joined the grouping on 2 May 1997.

${ }_{2}^{20}$ Article 4, Treaty on the West African Economic and Monetary Union (UEMOA).

${ }^{21}$ The economic union is a common market in which there is also a complete unification of monetary and fiscal policy.

${ }_{23}^{22}$ Article 16, UEMOA Treaty.

${ }^{23}$ Additional Act No 04/96 of 10 May 1996, enacting a transitory preferential tariff regime of exchanges within the UEMOA and its financing modality, modified by Additional Acts No 01/97 of 23 June 1997 and 04/98 of 30 December 1998 (http://www.uemoa.int/actes/1996/acte_additionnel_04_1996.htm). ${ }^{24}$ Regulation No 2/2002/CM/UEMOA of 23 May 2002.

${ }_{26}$ Details on UEMOA Regional Financial Market accessible at http://www.brvm.org/fr/presentation/marche.htm.

${ }^{26}$ Details on UEMOA sectoral policies accessible at http://www.uemoa.int/actes/2003/protocole_additionnel_04.htm.

${ }_{27}^{27}$ Details accessible at http://www.uemoa.int/actes/2004/CCE/acte_additionnel_03_2004.htm.

${ }^{28}$ UEMOA: 2006-2010 REP, Summary Report, 2001: 16.

${ }^{29}$ Details on the Declaration are accessible at http://www.uemoa.int/actualite/2004/IDeclarCCEJanv2004.pdf.

${ }^{30}$ Nigerian Business Info "Nigerian and FDI," 30 April 2002 (http://www.nigeriabusinessinfo.com/nigeriafdi2002.htm.

${ }_{32}^{31} \mathrm{~J}$. J. Bala. 'The Challenges and Opportunities of the Investment Environment in Nigeria', $2003: 7$.

${ }^{32}$ Source: United States' Statistics, Energy Information Administration (http://www.eia.doe.gov/emeu/cabs/ topworldtables 1_2.htm).

${ }_{34}^{33}$ NEEDS/Part 1, Chapter 1, 2004: 2, accessible at http://www.nigerianeconomy.com/downloads/part 1.pdf.

${ }_{35}^{34}$ Details on the Project accessible at http://www.heartofafrica.net/objectives.htm.

${ }^{35}$ NEEDS, Part 3, Chapter 7, 2004: 80-83 accessible at http://www.nigerianeconomy.com/downloads/part3.pdf.

${ }_{37}^{36}$ http://demographymatters.blogspot.com/2006/12/nigeria-population-census-results.htm.

${ }^{37} \mathrm{http}: / /$ www.uemoa.int/actualite/2004/IDeclarCCEJanv2004.pdf.

${ }_{39}^{38}$ UNTCAD 1998 Annual Report, quoted in Odenthal, 2001: 14).

39 African Competitive Report 2000/2001 (quoted in Bala, 2003: 5). 